\title{
CISTO ÓSSEO TRAUMÁTICO EM MANDÍBULA: RELATO DE CASO
}

Henrique Mateus Alves FELIZARDO ${ }^{1}$, Alexandre Augusto Sarto DOMINGUETTE ${ }^{2}$, Matheus Henrique Lopes DOMINGUETE ${ }^{3}$, Bruno Henrique Figueiredo MATOS ${ }^{3}$, Lucinei Roberto de OLIVEIRA ${ }^{4}$, Paulo Roberto DOMINGUETE

${ }^{1}$ Graduando em Odontologia pela Universidade Vale do Rio Verde - UninCor hmafelizardo@gmail.com

${ }^{2}$ Mestrando em Clínica Odontológica (Diagnóstico Bucal) pela UninCor alexandre.dominguette@gmail.com

${ }^{3}$ Professores da UninCor / Especialistas em CTBMF - Mestrandos em Clínica Odontológica (Diagnóstico Bucal) pela UninCor

${ }^{4}$ Professor da UninCor / Especialista em Periodontia e Patologia Bucal - Mestre em Estomatopatologia pela Unicamp

${ }^{5}$ Orientador e Professor da UninCor / Especialista em CTBMF - Mestre em Clínica Odontológica

(Diagnóstico Bucal) pela UninCor

\section{Palavras-Chave: Cisto ósseo simples, Cistos Maxilomandibulares, Mandíbula /patologia.}

\section{Resumo:}

O cisto ósseo traumático, simples, hemorrágico ou cisto solitário é classificado como uma lesão óssea não neoplásica e predomina-se no corpo e sínfise da mandíbula. Trata-se de uma cavidade intra-óssea delimitada por fina camada de tecido conjuntivo frouxo, sem revestimento epitelial. Sua etiologia ainda é desconhecida, onde a mais aceita é que ele se origine de traumas. É assintomático e comumente notado em exames radiográficos de rotina. Representa aproximadamente $1 \%$ dos cistos maxilares. Paciente V.O.R., 18 anos, gênero masculino, melanoderma, seu exame radiográfico apresentou imagem radiolúcida em região de sínfise mandibular. $\mathrm{Na}$ anamnese, relatou que sofreu queda há sete anos, e não se lembrava de traumatizar o mento. A ectoscopia e oroscopia não apresentaram alterações de normalidade. Na radiografia, observou-se lesão em sínfise mandibular radiolúcida, unilocular, bem definida e limitada por um halo radiopaco, se estendendo dos dentes 33 ao 45, sem expansão das corticais ósseas. Todos os elementos envolvidos na lesão responderam positivamente ao teste de vitalidade pulpar percussivo e térmico. A hipótese diagnóstica de cisto ósseo traumático foi evidenciada com a coleta de dados clínicos e analise da radiografia, sendo proposta biópsia excisional. Sob anestesia local, o paciente foi submetido à incisão no fórnice de vestíbulo do elemento 3.4 ao 4.4 e descolamento muco periosteal. Foi feita punção e observou-se sangue de coloração escura. A área da lesão foi exposta e acessada pela cortical óssea vestibular com peça reta e broca esférica nำ com irrigação de soro fisiológico 0,9\%; na área exposta notou-se secreção sanguinolenta, confirmando-se a hipótese diagnóstica Foi feita curetagem do leito com regularização dos bordos, irrigação com soro fisiológico e sutura. Após sete dias o paciente foi avaliado e verificou-se boa cicatrização. Paciente encontra-se em proservação. É necessário para o diagnostico de um cisto ósseo traumático: exame clínico, radiográfico e punção aspirativa. Tendo como principais diagnósticos diferenciais: ceratocisto odontogênico, tumor odontogênico adenomatóide, cisto residual, ameloblastoma ou granuloma central de células gigantes. A predileção é por jovens do gênero masculino, sendo a mandíbula a região de maior prevalência. Geralmente é assintomático. As formas de tratamento são ressecções, curetagem, enxerto ósseo, injeção de corticosteróides e de medula óssea autóloga. A recidiva é rara e é relacionada a intervenções inadequadas. 